\title{
ADAM KALBARCZYK \\ „Trudna jest ta mowa. Któż jej może słuchać?" O kurs podstawowy języka wiary
}

Trudna jest ta mowa. Któż jej może słuchać? (J 6,60)․ Te słowa, wypowiedziane przez uczniów Jezusa po wysłuchaniu Jego Mowy eucharystycznej, wyrażają też szemrania wielu współczesnych Jego wyznawców. Mówią oni, że język, jakim posługuje się dziś Jego Kościół, jest dla niemałej rzeszy ludzi niezrozumiały, przez co wiara chrześcijańska dociera do dzisiejszego człowieka z ogromnym trudem. Może to brzmieć jak zarzut, ale też jak wymówka - zwłaszcza ze strony tych, którzy mentalnie już dawno od Kościoła odeszli. Niemniej lekceważenie tych głosów byłoby poważnym jego błędem. Kto wie, czy język Kościoła jest dlatego niezrozumiały, bo zbyt często myli się w nim wiarę $\mathrm{z}$ wiedzą o Bogu, teologią czy naukowym dyskursem. A przecież żeby wierzyć, nie potrzeba studiować teologii. Większość świętych nigdy nie widziała wyższej uczelni od środka.

Ponieważ Kościół jest ze swej natury wspólnotą wiary, to jego mową, językiem jego modlitwy, przepowiadania, duszpasterstwa nie może być żaden inny język jak tylko język wiary. Jeżeli dzisiaj język ten jest dla wielu ludzi językiem obcym, to dlatego, że nigdy się go nie uczyli lub nie chcieli nauczyć, bądź nikt nie zechciał ich go nauczyć. Jeśli dzisiaj wielu ochrzczonych nie zna go ani czynnie, ani biernie, to dlatego, że nauczywszy się go kiedyś, nigdy nie mieli okazji go używać i po prostu go zapomnieli. Jest to mowa trudna, ale każdy jest w stanie ,przyswoić" sobie przynajmniej jej podstawy. Do tego zaś potrzebny jest w Kościele dostęp do czegoś, co można by nazwać - jak w dydaktyce języ-

Adam K A L B A R C Z Y K, ks. dr hab., adiunkt w Zakładzie Liturgiki i Homiletyki, Wydział Teologiczny Uniwersytetu im. Adama Mickiewicza w Poznaniu, e-mail: adamkal@amu.edu.pl

${ }^{1}$ Cytaty biblijne za: Pismo Święte Starego i Nowego Testamentu w przekladzie z języków oryginalnych. Poznań - Warszawa $1984^{4}$. 
ków obcych - „kursem podstawowym” języka wiary, za którym w niniejszym przedłożeniu optuję. Podjętą kwestię przedstawię w trzech etapach. W pierwszym spróbuję zdefiniować pojęcie języka wiary. W drugim ukażę liturgię Kościoła i Pismo Święte jako swoiste ,podręczniki” do nauki języka wiary. W trzecim zaś wskażę na duszpasterstwo, zwłaszcza diakonię, jako miejsce, w którym można uzyskać pomoc w poznawaniu i opanowaniu języka wiary.

\section{Co to jest język wiary?}

Jak jednak zdefiniować język wiary? W ważniejszych encyklopediach i leksykonach kościelnych trudno znaleźć hasło ,język wiary”. Trzeba się więc zadowolić hasłem , język religijny" w aspekcie filologicznym. Wynika zeń, że język wiary to język religijny w węższym znaczeniu, czyli język teologii ${ }^{2}$, traktatów teologicznych, liturgii, modlitw, Pisma Świętego, katechezy, kazań, potocznych wypowiedzi o Bogu i postawie ludzi względem Niego, a nawet język religijnej literatury pięknej. O jego specyfice decydują takie czynniki jak: religijna tematyka, z którą wiąże się odpowiedni dobór słów ${ }^{3}$ (np. „łaska”, „chwała”, „zbawienie”, świętość”, „sakramentalny” itp.); obecność w akcie mowy czynnika nadprzyrodzonego jako odbiorcy, nadawcy lub świadka aktu mowy; wspólnotowość, dzięki której teksty religijne pełnią funkcję integrującą ludzi (choć możliwe są też akty indywidualne, np. modlitwa prywatna); moc sprawcza (np. formuły sakramentów, słowa konsekracji); częste powiązanie ze znakami niewerbalnym (np. gesty, szaty, muzyka, plastyka, elementy teatru $)^{4}$. Ujęcie filologiczne nie wystarcza jednak do określenia tego, czym jest język wiary.

Teologia protestancka mówi o językowym charakterze wiary (niem. Sprachlichkeit des Glaubens), który od samego początku był jej centralnym motywem. Wiara jest dla niej nie tyle przyjęciem autorytatywnie ustalonego przez

\footnotetext{
${ }^{2}$ Język jest naturalnym polem dociekań teologii jako teorii mówienia o Bogu i medium umożliwiającym jej własny rozwój. Ponieważ jej celem jest zapewnienie solidnej i powszechnie obowiązującej podstawy znaczenia i prawdziwości jej wypowiedzi, musi ona też mieć bezpośrednie odniesienie do lingwistyki, czyli teorii języka. $Z$ tej racji zabiega ona np. o pierwszeństwo takich przesłanek lingwistycznych, które nie akcentują głównie ,,apriorycznych konstrukcji” i „dedukcyjnego zastosowania" (teoria języka sformalizowanego), lecz rekonstrukcję faktycznego posługiwania się językiem i jego system reguł oraz wyjaśnienie sposobów przekazywania znaczeń w codziennym życiu, gdyż jest ona nierozerwalnie związana $z$ doświadczeniem religijnym i jego interpretacją za pomocą języka w kontekście aktualnej teraźniejszości (teoria języka naturalnego). Zob.Teoria języka i teologia. W: K. R a h n e r, H. V orgrimle r: Maly stownik teologiczny. Tłum. T. M i e s z k ow s k i, P. P a c h c i a r e k. Warszawa 1987 kol. 491-492.

${ }^{3}$ Np. „Procesja Bożego Ciała przeszła ulicami Poznania” - „przeszła”, a nie ,przemaszerowała", bo przemaszerować może odział wojsk czy pochód pierwszomajowy, ale nie procesja eucharystyczna.

${ }^{4}$ Zob. I. B a je ro w a, J. P u z y n in a: Język religijny. W: Encyklopedia katolicka. T. VIII. Lublin 2000 kol. 19.
} 
Kościół kanonu zobiektywizowanych prawd skierowanych do rozumu i uczestnictwem w rycie Kościoła, lecz zaufaniem do Boga, zawierzeniem się Bogu, rozumianym jako „akt językowy”, ,akt mowy”, „wydarzenie językowe” (niem. sprachliches Geschehen). Wiara żyje tym wydarzeniem, gdyż bierze się - według św. Pawła - „ze słuchania” (Rz 10,17) .

Kościół katolicki na temat wiary mówi w swoim katechizmie tak: Wierzymy nie $w$ formuly, ale $w$ rzeczywistości, które one wyrażaja i których wiara pozwala nam »dotknąc'«. »Akt (wiary) wierzacego nie odnosi się do tego, co się wypowiada, ale do rzeczywistości (wypowiadanej) «. Zbliżamy sie jednak do tych rzeczywistości za pomoca formut wiary. One pozwalaja nam wyrażać i przekazywać wiare, celebrować ja we wspólnocie, przyswajać ja sobie i coraz bardziej nia żyć (KKK 170). W następnym zaś punkcie Kościół ukazuje siebie jako nauczyciela języka wiary, który jest potrzebny jego dzieciom do rozumienia tego, w co wierzą, i życia według tego, w co wierzą: Kościót, który jest »filarem i podpora prawdy" (1 Tm 3,15), zachowuje wiernie "wiare raz tylko przekazana świętym" (Jud 3). To Kościót zachowuje pamięć o stowach Chrystusa, to on przekazuje z pokolenia na pokolenie wyznanie wiary Apostołów. Jak matka uczy dzieci mówić, a przez to rozumieć i komunikować się, tak Kościót, nasza Matka, uczy nas języka wiary, by wprowadzać nas w rozumienie i życie wiary (KKK 171).

Papież Franciszek pojmuje język wiary jako „ojczysty”, „macierzyński” język dialogu Pana z Jego Kościołem. W adhortacji Evangelii gaudium pisze, że W wierze mówi się w kluczu »kultury ojczystej - „macierzyńskiej" ", w kluczu ojczystego - »macierzyńskiego« dialektu [por. 2 Mch 7,21. 27] (EG 139), i że ta „macierzyńska” mowa jest właśnie owym językiem dialogu Pana z Jego ludem, który się dokonuje w kręgu macierzyńsko kościelnym (zob. EG 140).

\section{Kościelne „podręczniki” do nauki języka wiary}

W jaki sposób Kościół uczy takiego języka? Może posłużyć się w tym celu dobrym katechizmem, tzn. takim, który pomaga odnaleźć istotne punkty i treściowe związki między poszczególnymi prawdami wiary. Ale nawet najlepszy katechizm jest jedynie suchym podręcznikiem „gramatyki” wiary oraz wykazem jej podstawowych „słówek” i „Zwrotów”, a nie „pierwszą czytanką", za pomocą której poznaje się mówiony, żywy język.

\section{Liturgia}

Znajomość żywego języka wiary zdobyć możemy przede wszystkim poprzez liturgię Kościoła i Pismo Święte, które to opowiadają wielką historię zba-

\footnotetext{
${ }^{5}$ Zob. M. i R. Fritz: Zur Sprachlichkeit des Glaubens. W: M. Fritz, R. Frit z (red.): Sprachen des Glaubens. Philosophische und theologische Perspektiven. Stuttgart 2013 s. 7-16.
} 
wienia, wielkie tajemnice naszej wiary i są przez to najważniejszymi obszarami użycia języka wiary. Liturgiczne modlitwy i pieśni, znaki i gesty stanowią podstawy języka wiary - i to w dwójnasób: po pierwsze, w myśl starożytnej zasady teologicznej lex orandi - lex credendi, modlitwa jest nie tylko wyrazem wiary, ale też jej źródłem (Kościół wierzy tak, jak się modli); po drugie, wiara stanowi w liturgii nie tyle przedmiot refleksji, co jest w niej przede wszystkim praktykowana ${ }^{6}$.

Odnowa liturgiczna zainicjowana przez Sobór Watykański II i jego konstytucję Sacrosanctum concilium zmierzała właśnie ku temu, by liturgia stała się miejscem prawdziwej wypowiedzi i praktyki ludu, i żeby eschatologiczna treść orędzia chrześcijańskiego nie była $w$ niej przekazywana tylko $w$ formie symbolicznej $i$ nazbyt złagodzonej ${ }^{7}$. Ażeby wierni pełniej rozumieli celebrowane misterium, Sobór zezwolił na używanie języków narodowych we Mszy św. (zob. OWMR 12-13). Mimo to jednak podniosły język liturgii - zwłaszcza mszalnych formularzy i modlitw eucharystycznych - jest dla wielu ludzi, szczególnie młodych, za trudny, niezrozumiały, pompatyczny. Mają oni wrażenie, że liturgia, teksty liturgiczne, ich język pochodzą z innego świata i są pomyślane dla innych, lepszych i pobożniejszych ludzi.

Zadaniem liturgii jest zwiastowanie, komunikowanie życia, umożliwianie dostępu do niego, ale często nie mówi już ona językiem życiowym, tracąc przez to kontakt z konkretnym życiem ${ }^{8}$. Dlatego dość powszechnie podejmowane są dziś próby ożywienia, uproszczenia i „tłumaczenia” języka liturgii za pomocą dodatkowych mniej lub bardziej sensownych symboli i opowieści. Prowadzi to jednak nierzadko do infantylizacji i przeładowania zarówno liturgii, jak też samego przekazu wiary ${ }^{9}$. Zdaniem Josefa Müllera, tylko żywa wiara może być wyrażona w żywym, a mimo to godnym tajemnicy, języku. Mowa i mówienie w liturgii obejmuja wtedy cała ludzka egzystencje jej uczestników ${ }^{10}$.

\section{Pismo Święte}

Wielką rolę w liturgii odgrywa Pismo Święte. Jest ono obecne w liturgii słowa - w czytaniach, w homilii - jak też w tekstach mszalnych modlitw i pieśni. Język Biblii jest nie tylko źródłowym językiem judaizmu i chrześcijaństwa, lecz także pierwotnym językiem wiary. Kościół na Soborze Watykańskich II odkrył

\footnotetext{
${ }^{6}$ Zob. T. Söding: Die Sprache des Glaubens. Alphabetisierung mit der Bibel - http: //www.ruhr-uni-bochum.de/imperia/md/content/nt/exegesemethodikundhermeneutik/sprache glaubens.pdf [Dostęp: 15.09.2013].

${ }^{7}$ Liturgia. W: K. R a h n e r, H. V o r g r i m l e r, dz. cyt., kol. 207.

${ }^{8}$ Zob. J. M ülle r: Pastoraltheologie. Ein Handbuch für Studium und Seelsorge, Graz Wien - Köln 1993 s. 129.

${ }^{9}$ Zob. A. S to c k: Rede, Gerede. Zur Sprache in der Liturgie. „Diakonia”. R. 1998 nr 2 s. $94-101$.

${ }^{10}$ J. M ü 11 e r, dz. cyt., s. 129; thum. A. K a 1 b a r c z y k.
} 
na nowo, że na kartach Pisma Świętego zapisane zostało „słownictwo podstawowe" języka wiary ${ }^{11}$.

Jak jednak przybliżyć, jak uczynić zrozumiałym dzisiejszemu człowiekowi język Pisma Świętego, który jest przecież językiem nieistniejącego już, odległego orientalnego świata? Teksty biblijne zostały napisane po hebrajsku i grecku, a większości ludzi dostępne są jedynie poprzez przekłady na różne współczesne języki. Teksty biblijne to, jak wiemy, ,wielowarstwowa tkanka”, a ich interpretacja bywa uzależniana od „okularów” czytelnika. Ostatnie dziesięciolecia pokazały, że możemy mieć tu do czynienia $\mathrm{z}$ różną optyką: np. optyką teologii wyzwolenia, optyką psychologii głębi czy optyką teologii feministycznej.

Słowo Boże poświadczone na kartach Pisma Świętego jest jednak czymś więcej niż słowo mówione. Jest ono zawsze wydarzeniem. To jest główna teza teologii słowa zawartej w Biblii. Katechizm Kościoła Katolickiego wyraża to tak: Boski zamyst Objawienia spetnia się równocześnie »przez wydarzenia i stowa wewnętrznie ze soba powiazane» oraz wyjaśniajace się wzajemnie (KKK 53).

Wypowiedziane słowo Boże stwarza i porządkuje kosmos: Bóg rzekt: »Niechaj się stanie świattość! «I stała się świattość (Rdz 1,3). Dlatego też Dekalog, „Dziesięć słów”, które zostały wypowiedziane przez Boga na Synaju wobec Mojżesza i przekazane przez niego Izraelitom, nie są zwyczajnymi nakazami i zakazami, lecz słowami życia, które dla człowieka wiary są „lampą” dla jego kroków i „światłem” na jego ścieżkach (por. Ps 119,105). Człowiek pokłada ufność w słowie Bożym, czeka na to słowo z utęsknieniem (por. Ps 119,81).

Słowo Boże jest niezawodne. Słowa proroków są skuteczne nie dlatego, że są ich własnymi słowami, lecz dlatego, że są włożonymi w ich usta słowami Boga, co zresztą za każdym razem podkreślali, mówiąc: „To mówi Pan”; „Słowo Jahwe”; „Wyrocznia Pana”. Pełne dramatycznych wydarzeń biografie proroków Starego Przymierza świadczą o tym, jak bardzo bano się skuteczności głoszonych przez nich słów ${ }^{12}$.

Są jednak w Biblii i takie sytuacje, w których mówienie może być niebezpieczne czy wręcz stwarza zagrożenie dla życia mówiącego. Starotestamentowi prorocy nader często tego doświadczali i dlatego ukrywali powierzone im Boże orędzie w symbolicznych gestach i czynnościach, jak np. Jeremiasz obnoszący jarzmo po Jerozolimie (por. Jr 27), oraz w przypowieściach, jak np. Natan wobec króla Dawida, który doprowadził do śmierci Uriasza, by zdobyć jego żonę Batszebę (por. 2 Sm 12,1-4).

\footnotetext{
${ }^{11}$ Zob. T. S ö d i n g, dz. cyt.

${ }^{12}$ Zob. M.-L. G u b l e r: So vielerlei Arten von Sprachen gibt es in der Welt, und keine ist ohne sinnvollen Laut... (1 Kor 14, 10f). Sprache und Sprachen,. „Diakonia”. R. 1998 nr 2 s. 75-86.
} 
Do środków wyrazu biblijnego języka wiary należy też milczenie. Niekiedy o wiele więcej można powiedzieć milcząc, jak np. Rispa, jedna z żon Saula, która przez kilka miesięcy czuwała milcząco przy zwłokach swoich straconych synów, których Dawid nie pozwalał pogrzebać (por. 2 Sm 21,10-14). Tam, gdzie ludzkie pojęcia i słowa natrafiają na granice, gdzie nam, ludziom, brakuje słów, pozostają jedynie gesty poruszenia i niemego protestu.

Nieco z tego niemego języka wiary odkryć możemy u św. Marka Ewangelisty - zwłaszcza w jego relacji z pójścia kobiet do grobu Jezusa. Dwukrotnie wskazuje on na kamień zamykający wejście do grobu. Zaznacza przez to koniec ludzkich możliwości: Kto nam odsunie kamień z wejścia do grobu? - pytały niewiasty. Gdy jednak spojrzały, zauważyły, że kamień został odsunięty, a był bardzo duży (Mk 16,3-4). Ewangelista nawiązuje tu do metaforyki prorockiej, w której nieme kamienie mogą krzyczeć głośniej niż słowa.

Jakiego języka możemy uczyć się od samego Jezusa? Jezus przede wszystkim przemierzał każdą drogę, przekraczał wszelkie granice ustanowione przez ludzi, żeby dotrzeć do tych, którzy się zagubili, którzy przeszli niejedno, którym odebrano prawo do wypowiadania się. Siadał do stołu z celnikami i grzesznikami. Uzdrawiał trędowatych, z opętanych wypędzał złe duchy, odpuszczał grzechy - nawet w szabat. Dobrą nowinę o zbawieniu wyrażał zatem w ,języku", który dla jego antagonistów był po prostu niedopuszczalny, niesłychany. Przede wszystkim jednak Jezus głosił swoją Ewangelię za pomocą słów - bardzo często w formie przypowieści. Aby ukazać ludziom zbawczą bliskość Boga, posługiwał się historiami wziętymi bezpośrednio z codziennego życia swoich słuchaczy.

Ale to Jezusowe mówienie „w przypowieściach” nie było wyłącznie opowiadaniem historii z pouczającą pointą. Decydujące w tych opowieściach jest to, że Ten, który je opowiada, sam jest przypowieścią Boga. Jezus żyje swoimi przypowieściami, żyje tym, co głosi. Głoszone w przypowieściach zbawcze orędzie uwidaczniało się w Jego czynach. To, co mówił i czynił, stanowiło jedno. I tak np. radość z odnalezienia zagubionej drachmy czy owcy uwidoczniła się w spotkaniu Jezusa z Zacheuszem, a radości z darowania niewyobrażalnie wysokiego długu w wysokości dziesięciu tysięcy talentów doświadczyło wielu ludzi, którym Jezus opuszczał grzechy. Właśnie ta nierozerwalna jedność słowa i czynu otwierała Jezusowi nie tylko ludzkie uszy, lecz przede wszystkim serca.

A jakim językiem posługiwali się apostołowie Jezusa, ci, których posłał na cały świat, by głosili Jego Ewangelię, by ewangelizowali? Św. Jan Apostoł napisał na początku swojej pierwszego listu: To wam oznajmiamy, co byto od początku, cośmy ustyszeli o Stowie życia, co ujrzeliśmy własnymi oczami, na co patrzyliśmy i czego dotykały nasze ręce... (1 J 1,1). Język apostołów to przede wszystkim język świadków, to słowa, które zrodziły się w spotkaniu z Bogiem. Ich słowa mają siłę i skuteczność przypominającą moc słów proroków Starego 
Przymierza. Siła i odwaga tych prostych ludzi, jak też zaangażowanie, z jakim głosili Ewangelię, wprawiły w zdumienie członków Sanhedrynu i udaremniły wszelkie próby zamknięcia im ust. Zastraszany Piotr odpowiedział: Rozsadźcie, czy stuszne jest w oczach Bożych bardziej stuchać was niż Boga? Bo my nie możemy nie mówić tego, cośmy widzieli i styszeli (Dz 4,19-20). Słowo Boże ciśnie się im po prostu na usta, dlatego św. Paweł powie: Biada mi, gdybym nie głosit Ewangelii (1 Kor 9,16).

To, że Ewangelia tak zdumiewająco szybko rozprzestrzeniła się po basenie Morza Śródziemnego, nie zawdzięczamy jedynie temu, że wszędzie mówiono wówczas po grecku, lecz przede wszystkim dlatego, że ci, którzy ją głosili, żyli tym, co głosili. Naoczni świadkowie życia, śmierci i zmartwychwstania Jezusa głosili Jego Ewangelię, tę samą Ewangelię, która ich samych do głębi poruszyła i całkowicie przemieniła. Głosili ją, bo nie została im dana tylko ku własnemu zbudowaniu, pokrzepieniu i pocieszeniu - jak pisze św. Paweł w Pierwszym Liście do Koryntian (por. 1 Kor 14,1-25). Głoszą ją, bo jest ona „słowem życia” nie tylko dla wybranych, lecz dla wszystkich.

Stąd wielkim problemem dla Apostoła Narodów było to, że zgromadzenia wspólnot chrześcijańskich w Koryncie zdominowane były przez posiadających dar języków, których nikt nie rozumiał, a mówiący nimi byli ,żądni darów duchowych" tylko dla siebie. Dlatego ustalając zasady korzystania z charyzmatów, ustanawia jednocześnie pierwszą zasadę przepowiadania, którą jest językowa zrozumiałość i zwięzłość: Na świecie - mówi św. Paweł (władający niejednym językiem!) - jest takie mnóstwo stów, ale żadne nie jest bez znaczenia. Jeżeli jednak nie będe rozumiat, co jakieś stowo znaczy, będę barbarzyńca dla przemawiającego, a przemawiajacy - barbarzyńca dla mnie[za barbarzyńce uchodzit wtedy ktoś, kto nie mówit po grecku]. [...]. W Kościele wolę powiedzieć pięć stów wedtug mego rozeznania, by pouczyć innych, zamiast dziesięć tysięcy wyrazów wedtug daru języków (1 Kor 14,10-11.19).

Kiedy św. Paweł (prawdopodobnie w Koryncie) pisał swój List do Rzymian - będący jego teologicznym testamentem - spoglądał na swoje wspaniałe dzieło ewangelizacyjne na Wschodzie: Oto od Jeruzalem i na calym obszarze aż po Ilirię dopetnitem głoszenia Ewangelii $(\mathrm{Rz} 14,19)$. Pisał o planowanej podróży do Jerozolimy i o planach misyjnych na zachodzie, w Hiszpanii. Dzieło, którego dokonał, było okupione cierpieniem, wyniszczeniem i niedostatkiem. Po tych ciężkich doświadczeniach napisał: To, co niegdyś zostało napisane, napisane zostało także dla naszego pouczenia, abyśmy dzięki cierpliwości i pociesze, jaka niosa Pisma, podtrzymywali nadzieję (Rz 15,4).

Dla Pawła - niegdysiejszego faryzeusza - to Pismo, czyli Biblia Hebrajska, była słowem Bożym, które jest nieodwołalne i stanowi fundament, jak też nadaje głębię Ewangelii Chrystusa. Zapisane słowo daje pociechę, cierpliwość i nadzieję 
temu, kto pragnie nim żyć. Jest to słowo wypowiedziane w języku wiary. A język ten - jak pisze papież Franciszek - to tonalność przekazująca odwage, oddech, moc, impuls" (EG 139). To jest właśnie biblijny język wiary.

\section{Diakonia językowa}

Wielu współczesnych ludzi nie zna tego języka. Dzisiejszy przekaz wiary jest zbyt abstrakcyjny, a liturgia Kościoła zbyt oderwana od konkretnego życia. Ludzie rozumieją język ekonomii, muzyki czy sportu, ale gdy trzeba wyrazić swoje osobiste przeżycia, pragnienia, doświadczenia religijne, gdy trzeba mówić o Bogu i wierze, to po prostu brakuje im słów.

Ten jednak, kto nie potrafi wypowiedzieć swojej wiary, jest poważnie ograniczony $\mathrm{w}$ jednym $\mathrm{z}$ najistotniejszym wymiarów człowieczeństwa. Dlatego człowiek ma prawo poznać i nauczyć się języka wiary. Ale - podobnie jak analfabetyzm nie jest problemem moralnym, lecz społecznym - tak też i w przestrzeni wiary ludzie stają się niemi zazwyczaj nie z własnej winy. Dlatego ci, którzy zapomnieli języka wiary lub nigdy go nie opanowali, potrzebują - jak każdy, kto znalazł się w trudnym położeniu - pomocy, diakonii, aby nauczyli się bądź nauczyli się od nowa wyrażać przed Bogiem swoje lęki i pragnienia, troski i potrzeby, radości i nadzieje, swoją wiarę i miłość. Kto zatem chce naśladować Jezusa w Jego służbie człowiekowi, powinien pomóc im zwerbalizować, ująć w słowa swoje życie i jednocześnie szukać takiego języka, który by pomógł im „rozumieć" wiarę poprzez odniesienie do życia ${ }^{13}$.

Przykładowo, zdarza się, że dziecko przygotowujące się do I Komunii św. nie potrafi się przeżegnać. Zamiast gorszyć się i czynić wyrzuty rodzicom, można ten fakt wykorzystać jako okazję do przybliżenia i dzieciom, i ich rodzicom symboliki krzyża jako znaku zbawienia w Jezusie Chrystusie i nadziei na zwycięstwo życia - oczywiście językiem dostosowanym do możliwości percepcyjnych jednych i drugich.

Inny przykład: Na mszach pogrzebowych kapłani natrafiają nierzadko na mur milczenia. Ludzie zebrani w kaplicy cmentarnej nie tylko nie wiedzą, jak się zachować w czasie liturgii, ale też nie potrafią wspólnie modlić się z księdzem. To jednak nie znaczy, że nie warto do nich mówić, że nie da się do nich dotrzeć i otworzyć ich na tajemnicę żywego Boga i nadzieję życia wiecznego z Nim. Można to uczynić już poprzez starannie czynione proste znaki liturgiczne i wypowiadane słowa modlitw, poprzez prostą, zrozumiałą, teologicznie jasną i poprawną homilię, przede wszystkim zaś poprzez towarzyszącą im auten-

${ }^{13}$ Zob. J. M ü 11 e r, dz. cyt., s. 169. 
tyczną próbę wczucia się w sytuację tych, którzy odprowadzają do grobu swoich bliskich.

Mamy wtedy do czynienia ze swoistą „elementaryzacją” przekazu wiary, która jednak także i dla „profesjonalistów” stanowi nie lada wyzwanie. Zmarły w 2011 r. arcybiskup Józef Życiński powiedział przed wieloma laty w rozmowie z Dorotą Zańko i Jarosławem Gowinem: Nie jest rzecza latwa wypracowanie języka, w którym niepojęte Boże tajemnice przedstawialoby się w sposób trafiajacy zarówno do sprzataczek, jak i do potencjalnych noblistów ${ }^{14}$. Chodzi bowiem o „koncentrację” przekazu wiary, ale trzeba wiele wysiłku ze strony duszpasterzy, kaznodziejów, by „koncentracja nie okazała się banalizacją,"

Konkludując, możemy powiedzieć, że ukierunkowanie na liturgię Kościoła i Pismo Święte w poznawaniu i uczeniu się języka wiary jest słuszne, ale też i niełatwe. Ważna jest katecheza liturgiczna, ważne jest czytanie Pisma Świętego, ważne jest Dzieło Biblijne, ważne są Tygodnie Biblijne, ważne są kręgi biblijne w parafii, ważne są bardziej życiowe homilie, dziś jednak potrzeba nam - jak twierdzi niemiecki biblista Thomas Söding - czegoś w rodzaju „diakonicznego duszpasterstwa biblijnego", ukierunkowanego na alfabetyzację w duchu Ewangelii współczesnych maluczkich i prostaczków, jąkających się, głuchych i niemych - tak bliskich przecież Bogu ${ }^{16}$. Celem takiego duszpasterstwa byłoby przybliżenie języka wiary wszystkim tym, którzy nie potrafią już wyrazić przed Bogiem tego, co im „dolega” i czego im brakuje. Byłby to dla nich najlepszy i najbardziej skuteczny kurs podstawowy języka wiary, opierający się głównie na spotkaniach, opiece, prowadzeniu, pomocy społecznej, czyli na ,praktykach językowych", na których można uczyć się języka wiary od tych, którzy nim w miarę dobrze lub biegle władają, od tych, dla których jest on - jak mówią Niemcy - Muttersprache (językiem matczynym, macierzystym), od tzw. native spaekers. Poznanie i opanowanie języka wiary według tej „metody” umożliwiłoby uczącym się równoczesne dojście do korzeni własnej tożsamości, tak iż byliby nie tylko w stanie wyrażać swoje troski i nadzieje w postaci „niewymownych jęków i westchnień" (por. Rz 8,22), lecz mogliby także w wolności dzieci Bożych - synów i córek - wołać: „Abba, Ojcze! (Rz 8,15).

${ }^{14}$ J. Ż y c i ński: Niewidzialne światło [rozmawiali: D. Z a ń k o i J. Gow in]. Kraków 1998 s. 249.

15 Tamże.

${ }^{16}$ Zob. tamże. 